\title{
Use of Chemicals and Biological Products in Aquaculture in Bangladesh
}

\author{
M. A. Hossain ${ }^{1}$, M. E. Hoq ${ }^{2}$ and M.A. Mazid² \\ ${ }^{1}$ Department of Fisheries, Bangabandhu Sheikh Mujibur Rahman Agricultural University \\ Gazipur1706, Bangladesh \\ ${ }^{2}$ Bangladesh Fisheries Research Institute, Mymensingh-2201, Bangladesh \\ *Corresponding author: msaifulpstu@yahoo.com
}

\begin{abstract}
The study attempt to document the chemicals and biological products that are in use in fish and shrimp culture in Bangladesh. Interviews were conducted with fish and shrimp farmers in Mymensingh aquaculture region, and two major shrimp producing regions, Khulna and Cox's Bazar. The study documented the use of 55 different chemicals and biological products in aquaculture in Bangladesh. The most commonly used products were vitamins and minerals (18), disinfectants (10), therapeutants (9) and water treatment compounds (8). Farmers in Mymensingh area were found to use 8 different chemicals and biological products, while the shrimp farmers in the south-western region (Khulna) used large number of such products than farmers in the other two regions. Laboratory trial of some of these products done by Bangladesh Fisheries Research Institute and the results are summarized in the paper.
\end{abstract}

Keywords: Chemicals, biological products, aquaculture

\section{Introduction}

In aquaculture, chemicals are used mainly in the treatment and prophylaxis of diseases, which constitute the largest single cause of economic losses. On the other hand, various chemicals/biological products are used in aquaculture as feed additives and water treatment compounds to target high fish production in the recent years. However, increasing use of the chemicals in aquaculture has lead to widespread public concern. The chemicals are different forms of limes, fertilizers, and various commercial forms of growth and water productivity enhancer products.

Many aquacultural chemicals degrade rapidly in aquatic systems. For example, formalin, a widely used parasiticide and fungicide, has a half-life of 36 hours in water (Katz, 1989). Furazolidone, an antibacterial, has a half-life of less than one day in sediments (Samuelsen et al., 1991). Other chemicals may persist for many months, retaining their biocidal properties. Some antibacterials, notably oxytetracycline, oxolinic acid and flumequine, can be found in sediments at least 6 months following treatment (Weston, 1996). Very little is known about the environmental fate of many aquaculture drugs with available data (Graslund et al., 2003).

Fish/shrimp culture in Bangladesh is sifting gradually towards commercial practice with the increase in stocking densities and use of commercial feeds. Management of water quality and maintenance of culture environment are becoming difficult, and thus the cultured species are becoming more susceptible to diseases. Farmers are now interested to use chemicals in feed, to maintain water quality, combat disease and increase production. So far, no significant work has been done on the impact of use of 
chemicals in aquaculture practices in Bangladesh. However, some work has been done on the impact of use of pesticide in agriculture on the fishery resources (Mazid and Haldar, 2005).

With the intensification of aquaculture, different farms are trying to introduce chemotherapeutics, feed additives, growth enhancers etc. to increase the production and combat disease outbreaks. Different pesticide companies are advocating for their chemicals and biological products as remedy to diseases and as growth enhancers. Unfortunately, complete information on the use of chemicals in aquacultural practices in Bangladesh is not yet available (Faruk et al., 2005). The present study provides a list of chemical and biological products that are in use in aquaculture in Bangladesh, and results of laboratory trial of some such products. Findings of this study will help to formulate guidelines for registration, licensing, regulation and guideline for the use of chemicals and biological products in aquacultural industry of the country.

\section{Materials and Methods}

\subsection{Survey on the use of chemicals and biological products in aquaculture}

A survey was conducted to find out the present status of the use of chemicals and biological products in fish/shrimp farming in Bangladesh. A set of questionnaires were prepared. Representative fish/shrimp farmers, extension workers, feed manufacturers and pesticide companies were interviewed. Data on product classification (pesticide, veterinary drug, medicated feedstuff, feed additive, poison, etc.), manufacturer's name, product name (official and scientific), active ingredients, chemical properties, efficacy, possible environmental impacts, etc. were collected and analyzed.
Altogether 65 respondents were interviewed in three major fish/shrimp producing regions in the country. The three regions were central regionMymensingh as aquaculture region, shrimp producing south-western region- Khulna and south-eastern region- Cox's Bazar. The chemicals and biological products documented in the survey were sorted into the following major groups: therapeutants, disinfectants, water treatment compounds, vitamins \& minerals, antibiotics, feed additives and hormons. Some products were identified with respect to chemical formula of active ingredient, whereas others were identified merely as a certain type of product (e.g. vitamins).

\subsection{Study the effects of chemicals on fish/shrimp and water environment}

Fish/shrimp was exposed to different chemicals commercially introduced by different pesticide companies in Bangladesh. A series of laboratory trials on available chemicals/biological products were conducted to observe the effects of chemicals on fish, shrimp or water.

\section{Results and Discussion}

\subsection{Field survey on use of chemicals/biological products}

Results of field survey indicates that the use of chemicals in aquaculture is not well established in the country. Farmers use different chemicals and biological products rather than most commonly used lime and fertilizers, in a limited scale. Piscicides are used in some Asian countries to control predators prior to stocking of ponds, but the use of antimicrobials and diseasecontrol chemicals is limited to a small percentage $(<5 \%)$ of the fish producers (Phillips, 2000). Although large numbers of chemicals are now introduced by different agrochemical dealer and pesticide companies, their wide scale use could not be quantified. The available chemicals and biological products that are in used in the country are summarized in Table 1 . 
Table 1. Chemicals and biological products that are in use in fish and shrimp culture in Bangladesh

\begin{tabular}{|c|c|c|c|c|c|}
\hline $\begin{array}{c}\text { Sl } \\
\text { No. }\end{array}$ & Product name & Producer & $\begin{array}{l}\text { Marketing } \\
\text { by }\end{array}$ & Ingredient & Purpose \\
\hline \multicolumn{6}{|c|}{ Therapeutants } \\
\hline 1 & Abacus & $\begin{array}{l}\text { Biostadt } \\
\text { Europe Ltd., } \\
\text { India }\end{array}$ & $\begin{array}{l}\text { Syngenta, } \\
\text { Bangladesh }\end{array}$ & $\begin{array}{l}\text { Lactobacillus } \\
\text { sporogenes, } \\
\text { L. acidophilis, } \\
\text { Bacillu subtilis, } \\
\text { B. licheniformis, } \\
\text { Saccharomyces } \\
\text { cerevisiae, sea } \\
\text { weed extract }\end{array}$ & $\begin{array}{l}\text { To improve efficacy of } \\
\text { digestive system, } \\
\text { absorption of nutrients, } \\
\text { digestion of complex } \\
\text { pertinacious materials, } \\
\text { feed consumption rate } \\
\text { and FCR, growth rate, } \\
\text { weight gain, body's } \\
\text { ability to resist stress } \\
\text { and the attacks of } \\
\text { pathogens etc. }\end{array}$ \\
\hline 2 & Ablaze & $\begin{array}{l}\text { Biostadt } \\
\text { Europe Ltd., } \\
\text { India }\end{array}$ & $\begin{array}{l}\text { Syngenta, } \\
\text { Bangladesh }\end{array}$ & $\begin{array}{l}\text { Doxycycline, } \\
\text { Collistine sulphate, } \\
\text { minerals etc. }\end{array}$ & $\begin{array}{l}\text { To prevent and cures a } \\
\text { broad range of viral and } \\
\text { bacterial diseases in fishes } \\
\text { build resistance against } \\
\text { diseases etc. }\end{array}$ \\
\hline 3 & Aqua grow & USA & $\begin{array}{l}\text { Eion Animal } \\
\text { Health } \\
\text { Products } \\
\text { Ltd., Dhaka }\end{array}$ & $\begin{array}{l}\text { DHA enriched } \\
\text { micro diet } \\
\text { supplement }\end{array}$ & $\begin{array}{l}\text { To increases larval } \\
\text { growth, disease } \\
\text { resistance etc. }\end{array}$ \\
\hline 4 & Ayumin & $\begin{array}{l}\text { Dabur India } \\
\text { Ltd., India }\end{array}$ & $\begin{array}{l}\text { Dabur } \\
\text { Ayurvet } \\
\text { Ltd., India }\end{array}$ & $\begin{array}{l}\text { Copper, cobalt, } \\
\text { magnesium, iron, } \\
\text { zinc, iodine, } \\
\text { methionine, lysine, } \\
\text { calcium, } \\
\text { phosphorus etc. }\end{array}$ & $\begin{array}{l}\text { To increase FCR, } \\
\text { growth and disease } \\
\text { resistance of fish etc. }\end{array}$ \\
\hline 5 & $\begin{array}{l}\text { Biolive } \\
\text { powder }\end{array}$ & - & $\begin{array}{l}\text { Biolab, } \\
\text { Chittagong }\end{array}$ & $\begin{array}{l}\text { Kalomegh, azoan, } \\
\text { radhoni, naxvum, } \\
\text { sodium selenite, } \\
\text { cobalt chloride, } \\
\text { herbal \& sincona }\end{array}$ & $\begin{array}{l}\text { To reduce ulcerative } \\
\text { disease, enteric } \\
\text { hemorrhage, hepatic } \\
\text { septicemia, tail rot, gill } \\
\text { rot of fish etc. }\end{array}$ \\
\hline 6 & Biophos & - & $\begin{array}{l}\text { Biolab, } \\
\text { Chittagong }\end{array}$ & $\begin{array}{l}\text { Ferum phos, trace } \\
\text { elements, herbal } \\
\text { extracts etc. }\end{array}$ & $\begin{array}{l}\text { To reduce ulcerative } \\
\text { disease, enteric } \\
\text { hemorrhage, hepatic } \\
\text { septicemia, tail rot, gill } \\
\text { rot of fish etc. }\end{array}$ \\
\hline 7 & Fish curepus & $\begin{array}{l}\text { M/S M.R. } \\
\text { Enterprise, } \\
\text { Dhaka }\end{array}$ & $\begin{array}{l}\text { M/S M.R. } \\
\text { Enterprise, } \\
\text { Dhaka }\end{array}$ & - & $\begin{array}{l}\text { To increase nutrient and } \\
\text { oxygen, to decrease } \\
\text { diseases, to cure } \\
\text { ulcerative disease }\end{array}$ \\
\hline 8 & $\begin{array}{l}\text { Oxycare } \\
\text { pH-7 }\end{array}$ & $\begin{array}{l}\text { Beijing Lily } \\
\text { Agrochemis, } \\
\text { China }\end{array}$ & $\begin{array}{l}\text { National } \\
\text { Agricare, } \\
\text { Bangladesh }\end{array}$ & - & $\begin{array}{l}\text { To enhance growth and } \\
\text { to treat diseases }\end{array}$ \\
\hline
\end{tabular}




\begin{tabular}{|c|c|c|c|c|c|}
\hline 9 & $\begin{array}{l}\text { Prokura } \\
\text { efinol-L }\end{array}$ & USA & $\begin{array}{l}\text { Eion Animal } \\
\text { Health } \\
\text { Products } \\
\text { Ltd., Dhaka }\end{array}$ & - & $\begin{array}{l}\text { To reduce stress and } \\
\text { mortality rate of fish }\end{array}$ \\
\hline \multicolumn{6}{|c|}{ Disinfectants } \\
\hline 10 & Aldrin & - & - & Aldrin & To kill predator \\
\hline 11 & $\begin{array}{l}\text { Copper } \\
\text { sulphate }\end{array}$ & - & - & $\mathrm{CuSO}_{4}$ & To control algal bloom \\
\hline 12 & Lime & - & - & $\mathrm{CaCO}_{3}, \mathrm{CaO}$ & $\begin{array}{l}\text { To increase } \mathrm{pH} \text { and to } \\
\text { disinfect water }\end{array}$ \\
\hline 13 & $\begin{array}{l}\text { Malachite } \\
\text { green }\end{array}$ & - & $\begin{array}{l}\text { Aquatic, } \\
\text { Dhaka }\end{array}$ & - & To control diseases \\
\hline 14 & Malathion & - & - & Organophosphate & To kill insects \\
\hline 15 & Phostoxin & - & - & - & $\begin{array}{l}\text { To eradicate weed } \\
\text { fishes }\end{array}$ \\
\hline 16 & Rotenone & - & $\begin{array}{l}\text { Aquatic, } \\
\text { Dhaka }\end{array}$ & Derris root & $\begin{array}{l}\text { To eradicate weed } \\
\text { fishes }\end{array}$ \\
\hline 17 & Sumithion & - & - & Organophosphate & To eradicate insects \\
\hline 18 & $\begin{array}{l}\text { Tea seed } \\
\text { powder }\end{array}$ & China & $\begin{array}{l}\text { Eion Animal } \\
\text { Health } \\
\text { Products } \\
\text { Ltd., Dhaka }\end{array}$ & $\begin{array}{l}\text { Natural saponin } \\
\text { and crude protein }\end{array}$ & $\begin{array}{l}\text { To eradicate weed } \\
\text { fishes, snails etc. }\end{array}$ \\
\hline 19 & Timsen & $\begin{array}{l}\text { United } \\
\text { Promotions } \\
\text { Inc, USA }\end{array}$ & $\begin{array}{l}\text { Eion Animal } \\
\text { Health } \\
\text { Products } \\
\text { Ltd., Dhaka } \\
\end{array}$ & $\begin{array}{l}\text { En-alkylbenzyl } \\
\text { dimithyl chloride }\end{array}$ & $\begin{array}{l}\text { To prevent bacterial, } \\
\text { viral, protozoan, algal } \\
\text { and fungal infection and } \\
\text { to reduce hardness }\end{array}$ \\
\hline \multicolumn{6}{|c|}{ Water treatment compounds } \\
\hline 20 & Alphamax & $\begin{array}{l}\text { Biolab, } \\
\text { Chittagong }\end{array}$ & $\begin{array}{l}\text { Biolab, } \\
\text { Chittagong }\end{array}$ & $\begin{array}{l}\text { Calcium, } \\
\text { Aluminium, } \\
\text { Magnesium, trace } \\
\text { elements, NPK }\end{array}$ & $\begin{array}{l}\text { To reduce acidity and } \\
\text { sulfide gas, maintain } \\
\text { oxygen balance, remove } \\
\text { lesion, and to reduce } \\
\text { antenna rot }\end{array}$ \\
\hline 21 & Banjo & $\begin{array}{l}\text { Biostadt } \\
\text { Europe Ltd., } \\
\text { India }\end{array}$ & $\begin{array}{l}\text { Syngenta, } \\
\text { Bangladesh }\end{array}$ & $\begin{array}{l}\text { Tetraacetyl } \\
\text { ethylene diamine, } \\
\text { sodium perborate, } \\
\text { absorbants, de- } \\
\text { odorizers }\end{array}$ & $\begin{array}{l}\text { To release required } \\
\text { amount of oxygen, to } \\
\text { relieve shrimp from } \\
\text { stress, to check the } \\
\text { growth of anerobic } \\
\text { bacteria, protozoa and } \\
\text { secondary pathogens }\end{array}$ \\
\hline 22 & Bio-Ade & USA & $\begin{array}{l}\text { Eion Animal } \\
\text { Health } \\
\text { Products } \\
\text { Ltd., Dhaka } \\
\end{array}$ & $\begin{array}{l}\text { Extract of Euca } \\
\text { cidigera }\end{array}$ & $\begin{array}{l}\text { To decrease ammonia } \\
\text { and to maintain healthy } \\
\text { environment in water }\end{array}$ \\
\hline 23 & Dolo-lime & - & $\begin{array}{l}\text { Ideal } \\
\text { Trading Ltd., } \\
\text { Dhaka }\end{array}$ & $\begin{array}{l}\text { Dolomite (Mg \& } \\
\text { Ca enriched lime) }\end{array}$ & $\begin{array}{l}\text { To reduce acidity of soil } \\
\text { and water, to release } \\
\text { calcium and magnesium, } \\
\text { to increase plankton, to }\end{array}$ \\
\hline
\end{tabular}




\begin{tabular}{|c|c|c|c|c|c|}
\hline & & & & & $\begin{array}{l}\text { reduce turbidity of } \\
\text { water }\end{array}$ \\
\hline 24 & Dropper & - & - & $\begin{array}{l}\text { Chloro alkyl } \\
\text { phenyl urea }\end{array}$ & $\begin{array}{l}\text { To inhibit growth of } \\
\text { blue green algae and } \\
\text { toxic plankton, to } \\
\text { control plankton growth } \\
\text { rate and water quality }\end{array}$ \\
\hline 25 & $\begin{array}{l}\text { Methylene } \\
\text { blue }\end{array}$ & - & $\begin{array}{l}\text { Aquatic, } \\
\text { Dhaka }\end{array}$ & Methylene blue & To treat pond water \\
\hline 26 & Oxyflow & - & - & - & $\begin{array}{l}\text { To increase oxygen in } \\
\text { water }\end{array}$ \\
\hline 27 & $\begin{array}{l}\text { Potassium } \\
\text { permanganate }\end{array}$ & - & - & $\begin{array}{l}\text { Potassium } \\
\text { permanganate }\end{array}$ & $\begin{array}{l}\text { To increase dissolved } \\
\text { oxygen content of water }\end{array}$ \\
\hline \multicolumn{6}{|c|}{ Vitamins and minerals } \\
\hline 28 & $\begin{array}{l}\text { Acimix } \\
\text { super-B }\end{array}$ & - & $\begin{array}{l}\text { ACI Animal } \\
\text { Health, } \\
\text { Dhaka }\end{array}$ & $\begin{array}{l}\text { Vitamins, } \\
\text { trace elements, } \\
\text { amino acid }\end{array}$ & $\begin{array}{l}\text { To increase growth, } \\
\text { FCR and disease } \\
\text { resistance capacity }\end{array}$ \\
\hline 29 & Agox & $\begin{array}{l}\text { Brookside } \\
\text { ara L.C., } \\
\text { USA }\end{array}$ & $\begin{array}{l}\text { Qadside } \\
\text { Bangladesh } \\
\text { Ltd.. }\end{array}$ & $\begin{array}{l}\text { BHA, Ethoxion, } \\
\text { EDTA, phosphoric } \\
\text { acid, citric acid, } \\
\text { mono/diglycerides, } \\
\text { calcium silicate, } \\
\text { silicon dioxide }\end{array}$ & $\begin{array}{l}\text { To increase appetite and } \\
\text { disease resistance }\end{array}$ \\
\hline 30 & $\begin{array}{l}\text { Alphavit } \mathrm{C}+\mathrm{E} \\
\text { premix }\end{array}$ & & $\begin{array}{l}\text { Biolab, } \\
\text { Chittagong }\end{array}$ & $\begin{array}{l}\text { Vitamin C, } \\
\text { Vitamin E, herbal } \\
\text { extracts }\end{array}$ & $\begin{array}{l}\text { To increase FCR and } \\
\text { growth and to reduce } \\
\text { stress }\end{array}$ \\
\hline 31 & Alphavit & $\begin{array}{l}\text { Biolab, } \\
\text { Chittagong }\end{array}$ & $\begin{array}{l}\text { Biolab, } \\
\text { Chittagong }\end{array}$ & $\begin{array}{l}\text { Vitamin } \mathrm{B}_{1}, \mathrm{~B}_{2}, \mathrm{~B}_{6} \text {, } \\
\mathrm{B}_{12} \text {, niacin, folic } \\
\text { acid, calpantho, } \\
\text { lysine, methionine, } \\
\text { iron, copper, } \\
\text { manganese, zinc, } \\
\text { boron, sodium } \\
\text { selinite, cobalt } \\
\text { chloride }\end{array}$ & $\begin{array}{l}\text { To increase plankton, } \\
\text { vitamin, minerals and } \\
\text { amino acid and disease } \\
\text { resistance }\end{array}$ \\
\hline 32 & Alphavit WS & $\begin{array}{l}\text { Biolab, } \\
\text { Chittagong }\end{array}$ & $\begin{array}{l}\text { Biolab, } \\
\text { Chittagong }\end{array}$ & $\begin{array}{l}\text { Vitamin } \mathrm{B}_{1}, \mathrm{~B}_{2}, \mathrm{~B}_{6} \text {, } \\
\mathrm{B}_{12}, \mathrm{~K} \text {, niacin, folic } \\
\text { acid, pantothenic } \\
\text { acid, choline, } \\
\text { lysine, methionine, } \\
\text { tryptophan, }\end{array}$ & $\begin{array}{l}\text { Toreduce tail and gill } \\
\text { rot, dropsy etc. }\end{array}$ \\
\hline 33 & Amnovit & $\begin{array}{l}\text { Hoechst } \\
\text { Roussel Vet } \\
\text { Ltd., India }\end{array}$ & - & $\begin{array}{l}\text { Vitamin } \mathrm{B}_{2}, \mathrm{~B}_{6}, \\
\mathrm{~B}_{12} \text {, niacin, folic } \\
\text { acid, calpantho, } \\
\text { lysine, methionine, } \\
\text { iron, copper, } \\
\text { manganese, zinc, }\end{array}$ & $\begin{array}{l}\text { To use as a non- } \\
\text { antibiotic growth } \\
\text { promoter }\end{array}$ \\
\hline
\end{tabular}




\begin{tabular}{|c|c|c|c|c|c|}
\hline & & & & boron & \\
\hline 34 & Anafish & - & - & $\begin{array}{l}\text { Vitamins, } \\
\text { minerals, antibiotic }\end{array}$ & $\begin{array}{l}\text { To enhance growth and } \\
\text { to prevent stress and } \\
\text { sickness }\end{array}$ \\
\hline 35 & Biophyl & $\begin{array}{l}\text { Avitec Lab., } \\
\text { France }\end{array}$ & - & $\begin{array}{l}\text { Minerals, vitamins, } \\
\text { amino acids }\end{array}$ & $\begin{array}{l}\text { To enhance growth and } \\
\text { to prevent stress and } \\
\text { sickness }\end{array}$ \\
\hline 36 & $\begin{array}{l}\text { Cencalcium- } \\
\text { plus }\end{array}$ & $\begin{array}{l}\text { Senavisa } \\
\text { Lab. Spain }\end{array}$ & $\begin{array}{l}\text { Impex } \\
\text { Marketing } \\
\text { Ltd. Dhaka }\end{array}$ & $\begin{array}{l}\text { Minerals, vitamins, } \\
\text { trace elements, } \\
\text { amino acids }\end{array}$ & $\begin{array}{l}\text { To better formation of } \\
\text { scales and bones }\end{array}$ \\
\hline 37 & Fish premix & USA & $\begin{array}{l}\text { Eion Animal } \\
\text { Health } \\
\text { Products } \\
\text { Ltd., Dhaka }\end{array}$ & Vitamins, minerals & $\begin{array}{l}\text { To increase health and } \\
\text { daily growth of fish and } \\
\text { shrimp }\end{array}$ \\
\hline 38 & M:H-10 & $\begin{array}{l}\text { Agrosystem, } \\
\text { Italy }\end{array}$ & $\begin{array}{l}\text { Genetica, } \\
\text { Bangladesh }\end{array}$ & $\begin{array}{l}\text { Protein, vitamins, } \\
\text { minerals, UGF }\end{array}$ & $\begin{array}{l}\text { To increase growth, } \\
\text { disease resistance and } \\
\text { plankton in water }\end{array}$ \\
\hline 39 & SPA & $\begin{array}{l}\text { Biostadt } \\
\text { Europe Ltd., } \\
\text { India }\end{array}$ & $\begin{array}{l}\text { Syngenta, } \\
\text { Bangladesh }\end{array}$ & $\begin{array}{l}\text { Protein, } \\
\text { cholesterol, } \\
\text { calcium, vitamin- } \\
\text { D, careotenoid }\end{array}$ & $\begin{array}{l}\text { To bind all powder form } \\
\text { medicinal ingredients, } \\
\text { nutrients and probiotic } \\
\text { supplements to the feed, } \\
\text { to make feed } \\
\text { supplements water stable } \\
\text { and bioavailable, to } \\
\text { improve pigmentation in } \\
\text { shrimps }\end{array}$ \\
\hline 40 & Super grow & China & $\begin{array}{l}\text { Eion Animal } \\
\text { Health } \\
\text { Products } \\
\text { Ltd., Dhaka }\end{array}$ & Zn premix & $\begin{array}{l}\text { To enhance growth and } \\
\text { molting of shrimp }\end{array}$ \\
\hline 41 & Vitafish-V & - & $\begin{array}{l}\text { Agro } \\
\text { Products, } \\
\text { Dhaka }\end{array}$ & $\begin{array}{l}\text { Vitamin } B_{1}, B_{2}, B_{6}, \\
\text { manganese } \\
\text { sulphate }\end{array}$ & $\begin{array}{l}\text { To increase appetite, } \\
\text { growth and disease } \\
\text { resistance, to help in } \\
\text { protein, lipid and } \\
\text { carbohydrate } \\
\text { metabolism }\end{array}$ \\
\hline 42 & Vitam-C & - & $\begin{array}{l}\text { Agriman, } \\
\text { Dhaka }\end{array}$ & $\begin{array}{l}\text { Vitamins, trace } \\
\text { minerals, amino } \\
\text { acids mix. }\end{array}$ & $\begin{array}{l}\text { To use as a vitamin, } \\
\text { trace mineral, amino } \\
\text { acid mix. for fish }\end{array}$ \\
\hline 43 & Vitam-P & - & $\begin{array}{l}\text { Agriman, } \\
\text { Dhaka }\end{array}$ & $\begin{array}{l}\text { Vitamins, trace } \\
\text { minerals, amino } \\
\text { acids mix. }\end{array}$ & $\begin{array}{l}\text { To use as a vitamin, } \\
\text { trace mineral, amino } \\
\text { acid mix. for catfish }\end{array}$ \\
\hline 44 & Vitam-S & - & $\begin{array}{l}\text { Agriman, } \\
\text { Dhaka }\end{array}$ & $\begin{array}{l}\text { Vitamins, trace } \\
\text { minerals, amino } \\
\text { acids mix. }\end{array}$ & $\begin{array}{l}\text { To use as a vitamin, } \\
\text { trace mineral, amino } \\
\text { acid mix. for shrimp }\end{array}$ \\
\hline 45 & Zeolite & $\begin{array}{l}\text { Zeoan } \\
\text { Forein Trade }\end{array}$ & $\begin{array}{l}\text { National } \\
\text { Agricare, }\end{array}$ & $\begin{array}{l}\text { Calcium, } \\
\text { magnesium, }\end{array}$ & $\begin{array}{l}\text { To remove toxic gases } \\
\text { as an alternative to lime }\end{array}$ \\
\hline
\end{tabular}




\begin{tabular}{|c|c|c|c|c|c|}
\hline & & Co., China & Bangladesh & $\begin{array}{l}\text { potassium, } \\
\text { phosphorus, } \\
\text { silicon, aluminum, } \\
\text { ferrous, sodium }\end{array}$ & and to produce plankton \\
\hline \multicolumn{6}{|c|}{ Feed additives } \\
\hline 46 & Flo-Bond & $\begin{array}{l}\text { Brookside } \\
\text { ara L.C., } \\
\text { USA }\end{array}$ & $\begin{array}{l}\text { Qadside } \\
\text { Banladesh } \\
\text { Ltd. }\end{array}$ & $\begin{array}{l}\text { Hydrated sodium } \\
\text { calcium alumino- } \\
\text { silicate }\end{array}$ & $\begin{array}{l}\text { To use as a micotoxin } \\
\text { binder in feed }\end{array}$ \\
\hline 47 & Novasil plus & USA & $\begin{array}{l}\text { Eion Animal } \\
\text { Health } \\
\text { Products, } \\
\text { Dhaka }\end{array}$ & Toxin binder & $\begin{array}{l}\text { To prevent alpha-toxin } \\
\text { in feed }\end{array}$ \\
\hline 48 & Oxistat & $\begin{array}{l}\text { Agril Ltd., } \\
\text { UK }\end{array}$ & - & $\begin{array}{l}\text { Butylated } \\
\text { hydroxytoluine, } \\
\text { butylated } \\
\text { hydroxyanisole, } \\
\text { ethoxyquin, } \\
\text { sodium citrate }\end{array}$ & $\begin{array}{l}\text { To use as anti-oxidant } \\
\text { for feed }\end{array}$ \\
\hline 49 & Pegabind & USA & $\begin{array}{l}\text { Eion Animal } \\
\text { Health } \\
\text { Products } \\
\text { Ltd., Dhaka }\end{array}$ & Pellet feed binder & To use as feed binder \\
\hline \multicolumn{6}{|c|}{ Antiobiotics } \\
\hline & Chlorsteclin & $\begin{array}{l}\text { Huazhong } \\
\text { Chia Co. } \\
\text { Ltd., China }\end{array}$ & $\begin{array}{l}\text { Novertis } \\
\text { (Bangladesh) } \\
\text { Ltd. }\end{array}$ & $\begin{array}{l}\text { Chlorotetracycline } \\
15 \%\end{array}$ & $\begin{array}{l}\text { To prevent and cure tail } \\
\text { and gill roty, dropsy, } \\
\text { EUS etc. }\end{array}$ \\
\hline 51 & $\begin{array}{l}\text { Oxy- } \\
\text { tetracycline }\end{array}$ & - & - & Oxytetracycline & To use as an antibiotic \\
\hline 52 & Tetracycline & - & - & Tetracycline & To use as an antibiotic \\
\hline \multicolumn{6}{|c|}{ Hormons } \\
\hline & Flash & $\begin{array}{l}\text { Biostadt } \\
\text { Europe Ltd., } \\
\text { India }\end{array}$ & $\begin{array}{l}\text { Syngenta, } \\
\text { Bangladesh }\end{array}$ & $\begin{array}{l}\text { Synthetic } \\
\text { Gonadotropin } \\
\text { releasing hormone } \\
\text { analogue }\end{array}$ & $\begin{array}{l}\text { To increase fertilization } \\
\text { and hatching rate and } \\
\text { minimize stress to the } \\
\text { brood stock }\end{array}$ \\
\hline 54 & Sex-F & - & $\begin{array}{l}\text { Aquatic, } \\
\text { Dhaka }\end{array}$ & - & \\
\hline 55 & Sex-M & - & $\begin{array}{l}\text { Aquatic, } \\
\text { Dhaka }\end{array}$ & - & To make all male fish \\
\hline
\end{tabular}

The surveyed products can be classified as therapeutants, disinfectants, water treatment compounds, vitamins and minerals, feed additive, antibiotic and hormon. Among them, the most commonly used products were vitamins and minerals (18), disinfectants (10), therapeutants (9) and water treatment products (8). Multinational pesticide company like
Syngenta has been marketing a variety of therapeutants, water treatment compounds and vitamins and minerals for use in aquaculture. The pesticide companies target shrimp and freshwater aquaculture industries for marketing of their products. Use of chemicals and other products was found to be more in shrimp culture than in carp culture and a variety of chemicals 
found in the markets are believed to be in use in shrimp culture. Farmers of Khulna region use the highest number of chemicals especially therapeutants and water treatment compounds than those of Cox's Bazar and Mymensingh regions. Vitamins and minerals are mostly used with feed in Mymensingh and Cox'S Bazar regions. Antibiotics and hormones are solely used in carp hatchery operation. It was revealed from the survey that each farmer of Mymensingh use at least 7 types of chemicals in aquaculture practices (pangus culture). Shrimp farmer of Khulna and Cox'S Bazar used 10 and 8 types of chemicals, respectively.

Results of the survey and discussion meetings with the farmers led to the conclusion that the farmers are mainly searching for solutions to the day-to-day problems they face, particularly when disease outbreaks are encountered in fish/shrimp ponds. Farmers select chemicals from their own experiences, suggestions from other farmers or from pesticide sellers. Many products documented in the survey were used for the purpose of preventing, treating or mitigating disease outbreaks, and the products used by a farmer may have been influenced by the presence or immediate risk of disease outbreaks. A variety of feed additives were reported to be used by the feed manufactures and progressive farmers to increase production, although efficacy of such additives was not well established.

The most common chemicals used in aquaculture are lime i.e. agricultural lime and quick lime, and fertilizers such as urea, TSP, MP etc. Dolomite also a form of lime now used in aquaculture practices. Liming does not cause environmental problems, and liming and inorganic fertilizer compounds do not cause food safety concerns. Fertilizers are highly soluble and release nutrients that can cause eutrophication of natural waters. An array of other substances is used less frequently in aquaculture including: oxidants, disinfectants, osmoregulators, algicides, coagulants, herbicides, and probiotics. These compounds or biological products quickly degrade or precipitate. Most of the substances used in pond aquaculture to improve soil or water quality cause little or no risk to food safety (Boyd and Massaut, 1999). However, high application rates of lime $(<2,250 \mathrm{~kg} / \mathrm{ha})$ in fish ponds reduced survival, growth, maturity index and fecundity of fish significantly (Konar et al., 1990).

\subsection{Characteristics of chemicals commonly used in aquaculture}

Chemicals have many uses in aquaculture, the types of chemicals used depending on the nature of the culture system and the species being cultured. Since the first true antibacterial agents were introduced in the 1930s, users have been coping with the emergence of drug resistance among target organisms. As each new drug was developed, major successes in therapy were achieved but, within a few years, the first cases of drug resistant strains began to appear. In intensive aquaculture antibacterial agents are used universally to treat bacterial disease and there is widespread prophylatic use. The most common routes of application are oral or by immersion. In both the cases, significant quantities of antibacterial may reach the environment and lead to the selection of resistance. Table 2 present the chemicals approved for aquaculture.

\subsection{Marketing and testing of chemicals}

In Bangladesh, there is no specific legislation regarding the use of therapeutic drugs and chemicals in aquaculture. As a result, their uses are unregulated. Most of the drugs are similar to those that are used in human medicine, while the chemicals used in aquaculture are the same as those used for agricultural purposes. Recently, the pesticide companies are marketing directly many products for aquaculture (Table 1). There is no registration system for importation of chemicals for use in aquaculture. As consequence of the expansion of aquaculture, chemical usage has become increasingly a part of management. 
Table 2. List of chemicals approved for aquaculture*

\begin{tabular}{|c|c|}
\hline Product & Use as \\
\hline \multicolumn{2}{|l|}{ THERAPEUTANTS } \\
\hline Acetic acid & Parasiticide \\
\hline Formalin & Parasiticide and fungicide \\
\hline $\begin{array}{l}\text { Romet } 30 \\
\text { (sulfadimethoxine and orthomeprim) }\end{array}$ & Bactericide \\
\hline Salt & Osmoregulatory enhancer \\
\hline Sulfamerizne & Bactericide \\
\hline Oxytetracycline (Terramycin) & Bactericide \\
\hline \multicolumn{2}{|l|}{ DISINFECTANTS } \\
\hline Calcium hypochlorite & Disinfectant, algicide, and bactericide \\
\hline \multicolumn{2}{|l|}{ WATER TREATMENT } \\
\hline Fluorescein sodium & Dye \\
\hline Lime (calcium hydroxide, oxide, or carbonate) & Pond sterilant \\
\hline Potassium permanganate & Oxidizer and detoxifier \\
\hline Rhodamine B and WT & Dye \\
\hline Copper sulfate & Algicide and herbicide \\
\hline Copper, elemental & Algicide and herbicide \\
\hline $2,4-\mathrm{D}$ & Herbicide \\
\hline Diquat dibromide & Algicide and herbicide \\
\hline Endothall & Algicide and herbicide \\
\hline Simazine & Algicide and herbicide \\
\hline \multicolumn{2}{|l|}{ Clean-Flo (aluminum sulfate, } \\
\hline Calcium Sulfate, and boric acid) & Algicide and herbicide \\
\hline Glyphosate & Herbicide \\
\hline Potassium ricinoleate & Algicide \\
\hline Xylene & Herbicide \\
\hline \multicolumn{2}{|l|}{ ANESTHETICS } \\
\hline Carbonic acid & Anesthetic \\
\hline MS 222 (tricaine methane-sulfonate) & Anesthetic and sedative \\
\hline Sodium bicarbonate & Anesthetic \\
\hline
\end{tabular}

\footnotetext{
*Chemicals registered or approved by the U.S. Food and Drug Administration for use in food fish culture. Source: ICES (1988).

Various types of commercial products are produced to meet the demand. There is an increasing level of suppliers also. Some suppliers import the products and some producers produce the products locally. Efficacy of most of the products is generally not tested before marketing.

contact Department of Fisheries or Ministry of Fisheries and Livestock for testing their products before marketing. They are ultimately referred to the Bangladesh Fisheries Research Institute (BFRI) for testing their products. Some times they directly contact BFRI for testing.
} A few leading pesticide/marketing companies 
Table 3. Laboratory trial of some chemicals to be used in aquaculture

\begin{tabular}{|c|c|c|c|c|}
\hline $\begin{array}{l}\text { Sl. } \\
\text { No } \\
\text {. }\end{array}$ & $\begin{array}{l}\text { Product name and } \\
\text { manufacturer/impo } \\
\text { rter }\end{array}$ & $\begin{array}{l}\text { Ingredients and } \\
\text { recommended dose }\end{array}$ & Probable use/benefits & Results and remarks \\
\hline \multicolumn{5}{|c|}{ Therapeutant } \\
\hline 1. & $\begin{array}{l}\text { Abacus } \\
\text { Syngenta } \\
\text { Bangladesh Ltd. }\end{array}$ & $\begin{array}{l}\text { Lactobacillus sporogenes, } L \text {. } \\
\text { acidophillus, Bacillus } \\
\text { subtilis, B. licheniformis, } \\
\text { Saccharomyces cervisiae, } \\
\text { Sea weed extract, Enzymes, } \\
\text { Vitamin } \mathrm{C}, \mathrm{B}_{1} \& \mathrm{~B}_{6} \text {, Sodium } \\
\text { benzoate etc. }\end{array}$ & 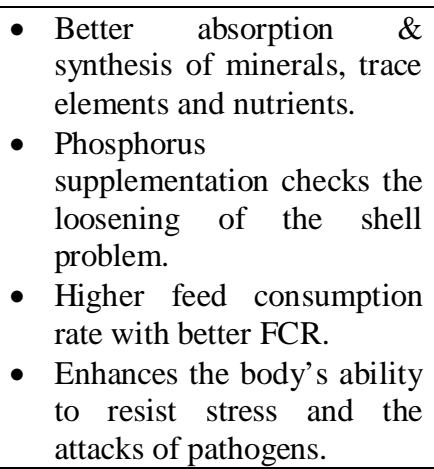 & $\begin{array}{l}\text { - Abacus administrated with feed to } \\
\text { observe juvenile shrimp growth. The } \\
\text { increases in weight was negligible. } \\
\text { - No significant change in water quality } \\
\text { parameters changes was observed after } \\
\text { application of Abacus. } \\
\text { - Bacteria Vibrio spp. was identified } \\
\text { from diseased shrimp. Abacus did not } \\
\text { act as growth promotor of shrimp. } \\
\text { However, it acted significantly to } \\
\text { control disease in shrimp. }\end{array}$ \\
\hline 2. & $\begin{array}{l}\text { Ablaze } \\
\text { Syngenta } \\
\text { Bangladesh Ltd. }\end{array}$ & $\begin{array}{l}\text { Doxycline, } \\
\text { sulphate, mineral mixture } \\
\text { with essential vitamins. }\end{array}$ & 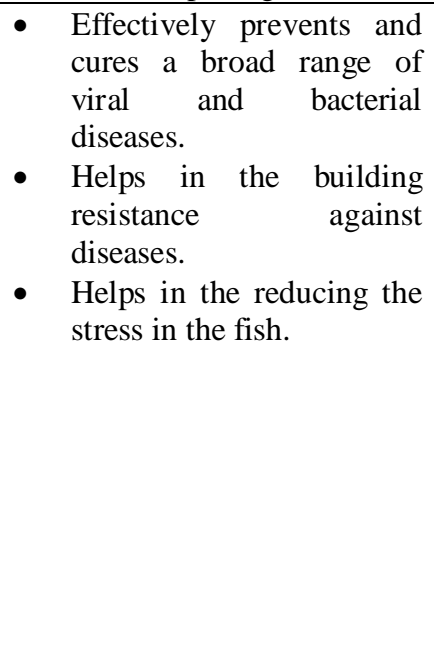 & $\begin{array}{l}\text { - In aquarium, Ablaze resulted } 20-25 \% \\
\text { curing of diseased Pangas fish, while } \\
\text { no individual survived in the control } \\
\text { group. In cistern trial, } 22-25 \% \text { diseased } \\
\text { pangas cured, while the control group } \\
\text { showed only 5\% improvement. } \\
\text { - In experimental ponds, Ablaze showed } \\
35 \% \text { improvement in diseased pangus. } \\
\text { In farmer's polyculture pond, 55\% } \\
\text { affected rohu, catla, mrigal, sarputi and } \\
\text { silver carp were cured. } \\
\text { - Water quality parameter in pond } \\
\text { showed that pH and alkalinity were } \\
\text { increased due to application of Ablaze, } \\
\text { whereas harmful ammonium was wa } \\
\text { reduced in water. } \\
\text { - Quantitative plankton study showed }\end{array}$ \\
\hline
\end{tabular}




\begin{tabular}{|c|c|c|c|}
\hline & & & $\begin{array}{l}\text { significant reduction in number } \\
\text { plankton/L of pond water after } \\
\text { application of Ablaze. }\end{array}$ \\
\hline \multicolumn{4}{|l|}{ Disinfectant } \\
\hline $\begin{array}{ll}\text { 3. } & \text { Calix } \\
& \text { Hadeeka }\end{array}$ & $\begin{array}{l}\text { Rotenone } \\
\text { Dose- } 36 \mathrm{~g} / \mathrm{dec} .\left(40 \mathrm{~m}^{2}\right) \text { for } 2 \\
\text { ft. water depth. }\end{array}$ & $\begin{array}{l}\text { Control of unwanted and } \\
\text { undesirable fish species. }\end{array}$ & $\begin{array}{l}\text { Cent percent mortality of test fish, } \\
\text { Barbodes gonionotus was observed by the } \\
\text { application of recommended dose. Calix } \\
\text { has lethal toxic affect on fish. }\end{array}$ \\
\hline \multicolumn{4}{|c|}{ Water treatment compound } \\
\hline $\begin{array}{l}\text { 4. Aqua Nourish } \\
\text { M/S Aqua } \\
\text { Chemicals }\end{array}$ & $\begin{array}{l}\text { Silica, Calcium, Magnesium, } \\
\text { Sodium, Potassium, Iron and } \\
\text { Aluminum } \\
\text { Dose- } 50 \mathrm{~kg} / \mathrm{ha}\end{array}$ & $\begin{array}{l}\text { Helps to increase } \mathrm{pH} \text {, } \\
\text { dissolved oxygen, reduces } \\
\text { turbidity and un-ionized } \\
\text { ammonia in water. }\end{array}$ & $\begin{array}{l}\text { Application of Aqua Nourish increased } \\
\mathrm{pH} \text {, dissolved oxygen, and reduced } \\
\text { turbidity and total ammonia in pond water. }\end{array}$ \\
\hline $\begin{array}{ll}\text { 5. } & \text { Bannzo } \\
& \text { Syngenta } \\
& \text { Bangladesh Ltd. }\end{array}$ & $\begin{array}{l}\text { Tetraacetyl etylene diamine, } \\
\text { sodium perborate, } \\
\text { absorbents, de-odorizers } \\
\text { Dose- } 500 \mathrm{~g} / \mathrm{ha}\end{array}$ & $\begin{array}{l}\text { - Releases required amount } \\
\text { of oxygen and helps in } \\
\text { restoring the pond bottom. } \\
\text { - Hinder the growth of } \\
\text { anaerobic bacteria, protozoa } \\
\text { and secondary pathogen } \\
\text { like Bacculovirus. }\end{array}$ & $\begin{array}{l}\text { Banzo can increase and maintain oxygen } \\
\text { level of pond. Application of Banzo can be } \\
\text { helpful in case of sudden fall of } \mathrm{O}_{2} \text { level in } \\
\text { shrimp pond. }\end{array}$ \\
\hline $\begin{array}{ll}\text { 6. } & \text { Dolomite } \\
\text { Moonlit Feeds } \mathrm{C} 0 \text {. } \\
\text { Ltd. }\end{array}$ & $\begin{array}{l}\text { Calcium, Magnesium, } \\
\text { Potassium paramagnet, } \\
\text { Potash alum } \\
\text { Dose- } 15-20 \mathrm{~kg} / \mathrm{ha}\end{array}$ & $\begin{array}{l}\text { Provides nutrients for } \\
\text { development of micro flora } \\
\text { and fauna in pond water. It } \\
\text { increases pH and reduces } \\
\text { turbidity in water. }\end{array}$ & $\begin{array}{l}\text { Application of Dolomites increases pH, } \\
\text { and alkalinity and also natural food } \\
\text { organisms in pond water. }\end{array}$ \\
\hline $\begin{array}{ll}\text { 7. } & \text { Matrix } \\
\text { Hadeeka }\end{array}$ & $\begin{array}{l}\text { Silicon oxide, Ferrous oxide, } \\
\text { Calcium oxide, Magnesium } \\
\text { oxide } \\
\text { Dose: } \\
\text { Pond preparation- } \\
125 \mathrm{~kg} / \mathrm{ha} \\
\text { Culture management- } \\
50 \mathrm{~kg} / \mathrm{ha}\end{array}$ & $\begin{array}{l}\text { Helps to increase } \mathrm{pH} \\
\text { dissolved oxygen and plankton } \\
\text { biomass in water and reduces } \\
\text { turbidity and un-ionized } \\
\text { ammonia }\end{array}$ & $\begin{array}{l}\text { Application of Matrix increases pH, } \\
\text { dissolved oxygen, total alkalinity, } \\
\text { ammonia and plankton biomass ( }>30 \%) \text { in } \\
\text { pond water. }\end{array}$ \\
\hline
\end{tabular}

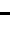




\begin{tabular}{|c|c|c|c|}
\hline $\begin{array}{ll}\text { 8. } & \text { Mutiplex } \\
\text { Karnataka Agro } \\
\text { Chemicals, India }\end{array}$ & $\begin{array}{l}\text { Zinc, Magnesium, } \\
\text { Manganize, Boron, } \\
\text { Potassium, Calcium, } \\
\text { Molybdenum, Copper, Iron } \\
\text { and Cobalt } \\
\text { Dose- Initially } 25 \mathrm{~kg} / \mathrm{ha} . \\
\text { Repeat } 10-15 \mathrm{~kg} / \mathrm{ha} \text { once in } \\
\text { two months. }\end{array}$ & $\begin{array}{l}\text { Provides nutrients for } \\
\text { development of micro flora } \\
\text { and fauna including planktons } \\
\text { in pond water. }\end{array}$ & $\begin{array}{l}\text { Application of Multiplex has increased } \\
\text { plankton in pond water. }\end{array}$ \\
\hline \multicolumn{4}{|l|}{ Feed additive } \\
\hline $\begin{array}{ll}\text { 9. } & \text { SPA } \\
\text { Syngenta } \\
\text { Bangladesh Ltd. }\end{array}$ & $\begin{array}{l}\text { Each } 10 \mathrm{~g} \text { contains } \\
\text { Protein } 100 \mathrm{mg} \text {, Cholesterol } \\
100 \mathrm{mg} \text {, Calcium } 10 \mathrm{mg} \text {, } \\
\text { Vitamin D } 20 \mu \mathrm{g} \text {, Carotenoid } \\
50 \mu \mathrm{g} .\end{array}$ & $\begin{array}{l}\text { - Water stable and increases } \\
\text { the bioavailability of the } \\
\text { feed supplements. } \\
\text { - Enrichment with carotenoid } \\
\text { content, which improves } \\
\text { pigmentation in shrimp. } \\
\text { - Easily digestible. }\end{array}$ & $\begin{array}{l}\text { - SPA showed no positive or negative } \\
\text { effect on growth and survival of fish } \\
\text { and shrimp in a } 28 \text { days rearing trial. } \\
\text { - However, SPA is water stable and can } \\
\text { effectively be used in feed formulation } \\
\text { as a binder. }\end{array}$ \\
\hline \multicolumn{4}{|l|}{ Hormon } \\
\hline $\begin{array}{ll}\text { 10. Flash } \\
\text { Syngenta } \\
\text { Bangladesh Ltd. }\end{array}$ & $\begin{array}{l}\text { Per } 10 \mathrm{ml} \text { contains Synthetic } \\
\text { gonadotropein releasing } \\
\text { hormone } 0.002 \% \text {, } \\
\text { Domperidon } 0.998 \% \text {, } \\
\text { Prepilene glycol 99.000\% } \\
\text { Dose- } 0.30-0.50 \mathrm{ml} \text { for } \\
\text { female and } 0.10-0.30 \mathrm{ml} \text { per } \\
\mathrm{kg} \text { body wt. of male }\end{array}$ & $\begin{array}{l}\text { Release of quality egg and } \\
\text { thereby production of healthy } \\
\text { spawn at mass scale by a } \\
\text { female fish with reduced } \\
\text { mortality. }\end{array}$ & $\begin{array}{l}\text { Flash fish hormon is found to be good } \\
\text { inducing agent for fish breeding of catla, } \\
\text { rohu and mrigal. }\end{array}$ \\
\hline
\end{tabular}



On the other hand, most of the suppliers of the country are indiscriminately marketing their products without prior test. Test results of 10 chemicals (2 therapeutants, 5 water treatment compounds and one each of disinfectant, feed additive and hormone group as reported by BFRI are presented in Table 3. Most of the water treatment compounds were found to be effective for purpose as stated by the manufactures/ suppliers. However, field level trials are required to establish the usefulness of these chemicals in our aquatic environment.

\section{Conclusion and Recommendations}

On a worldwide basis, only a small number of chemicals are legally approved for use in aquaculture. Chemicals can react differently in water depending upon the water quality, the target species and the life stage of the species. Water quality factors such as temperature, $\mathrm{pH}$, alkalinity and organic matter content can often have a bearing on the effectiveness or toxicity of a chemical. Larval stages and younger fish are usually more sensitive to chemicals. Furthermore, a fish already weakened by stress or disease may succumb to a "normal" chemical dose. Recommended dosages and methods of application should be followed closely. To avoid complications following chemical application, a simple "bioassay" can be conducted to determine the response to the treatment. A sample of fish from the pond or tank is placed in a small container and treated with the proposed chemical and dosage. The test should be run using water from the pond or tank to be treated. Following recommendations may be considered for judicial use of chemicals in the country:

- Undertake proper labeling of drugs/chemicals (ingredients, methods of use, handling, risks etc.) and undertake responsibilities for substantiating claims on products.
- When multiple chemical alternatives are available, farmers should select drugs not only on the basis of efficacy data but also on the basis of available information regarding environmental persistence, potential effects on non-target organisms, propensity to stimulate microbial resistance and rate of residue elimination.

- Scientists need to conduct more research on chemical use in aquaculture to ensure their effectiveness and safe uses.

- Standards for aquaculture-grade chemicals and their use should be set and enforced.

\section{Acknowledgements}

The authors would like to acknowledge the financial grant received from the Ministry of Science, Information and Communication Technology, Govt. of the Peoples Republic of Bangladesh to carry out the study.

\section{References}

Boyd, C.E. and Massaut, L. 1999. Risks associated with the use of chemicals in pond aquaculture. Aquaculture Engineering, 20(2). 113-132.

Faruk, M.A.R., Sultana, N. and Kabir, M.B. 2005. Use of chemicals in aquaculture in Mymensingh district, Bangladesh. Bangladesh Journal of Fisheries, 29(1-2): 1-10.

Graslund, S., Holmstrom, K.and Wahlstrom, A. 2003. A field survey of chemicals and biological products used in shrimp farming. Marine Pollution Bulletin, 46: 81-90

ICES (International Council for the Exploration of the Sea, Denmark). 1988. Environmental impact of mariculture. Cooperative Research Report No. 154, 84p.

Katz, G. 1989. Towards safe and effective use of chemicals in coastal aquaculture. Rep. Stud. GESAMP, 65: 40p.

Konar, S.K., Ghosh, T.K. and Dey, M. 1990. Hazards of aquatic pollution, its complexity and abatement measures. Proc. of the 
Second Indian Fisheries Forum, 27-31 May, 1990. Mangalore, India. 195-198pp.

Mazid, M.A. and Haldar, G.C. 2005. Harmful Effects of Pesticides used in Rice Fields on Fish and Aquatic Animals. Extension Manual No. 26. Bangladesh Fisheries Research Institute, Mymensingh, p 16.

Phillips, M. 2000. The Use of Chemicals in Carp and Shrimp Aquaculture in Bangladesh, Cambodia, Lao PDR, Nepal, Pakistan, Sri Lanka and Viet Nam. Proc. of the Meeting on the Use of Chemicals In Aquaculture in Asia, 20-22 May 1996; Tigbauan, Iloilo, Philippines. Southeast Asian Fisheries
Development Center Aquaculture Department Tigbauan, Iloilo, Philippines. 75-86pp.

Samuelsen, O.B., Solheim, E. and Lunestad, B.T. 1991. Fate and microbiological effects of furazolidone in marine aquaculture sediment. Science of Total Environmental 108: 275-283.

Weston, D.P. 1996. Ecological effects of the use of chemicals in aquaculture. Proc. of the meeting on the use of chemicals in aquaculture in Asia, 20-22 May, 1996. Tigbauan, Iloilo, Philippines, 23-3 
